\title{
PIONEER
}

VOLUME 13, Issue 1, June 2021: 16-25

\section{AN ANALYSIS ON THE USE OF COHESION AND COHERENCE IN STUDENTS' WRITING}

\author{
${ }^{1}$ Rizky Takriyanti \\ ${ }^{1}$ Jambi University \\ Irizkytakriyanti02@gmail.com
}

${ }^{2}$ Fransisko Chaniago*

${ }^{2}$ The State Islamic University of Sulthan Thaha

2ip.fransisco@uinjambi.ac.id

${ }^{3}$ Hamdan

${ }^{3}$ The College for Islamic Studies (STAI) Syekh Maulana Qori

${ }^{3}$ hamdan@staismqbangko.ac.id

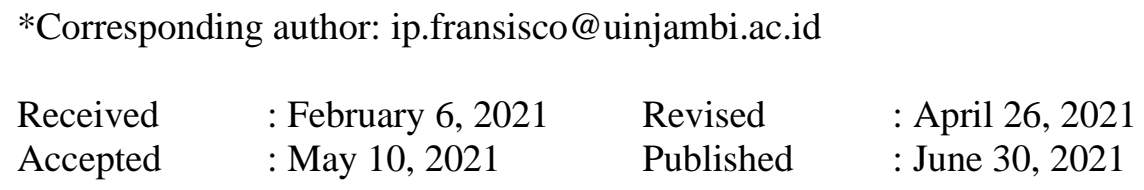

\begin{abstract}
This study is aimed at knowing the types of cohesion and coherence uses in writing a descriptive text by English Education Program students. The researcher focused on lexical cohesion, repeated key nouns, and consistent pronouns. The method used in this study is a qualitative. The data were collected by using a test and documentation. Participants of the research were twenty two students. The finding showed that nine students used fifteen items of reiteration and one student used collocation. In coherence, the researcher found that all students used repeated key nouns in their writing with 131 items used. Then, fifteen students used sixteen items of consistent pronouns. From the research, it can be concluded that the students used cohesion and coherence well in their writing.
\end{abstract}

Keywords: coherence, cohesion, descriptive texts, writing skills

\section{INTRODUCTION}

There are two kinds of communication. They are verbal and non-verbal communication. There are two kinds of verbal communications; they are in form of oral and written communication. Oral communication is used when we talk to others, and the written communication- is used when people communicate through a letter, a memoand any other writte forms. However, Harmer (2001, p.337) states that to create a good writing, grammar, vocabulary, issued of letter, words, and text formation are involved. To be able to do this, we need to learn how to make a good writing. 
Learning about writing is important in life. According to Zemach and Rumisek (2005, p. 54), the learning of writing is important because of some reasons. First, writing reinforces the grammatical structure, idiom, and vocabulary. Second, when someone writes, she or he has a chance to be adventurous with the language. The last,awriter can be involved with the language, with himself or herself, and with the readers.

\section{REVIEW OF LITERATURE}

Halliday and Hasan (as cited in Kurniasih, 2015, p. 2) explain that a text is considered good if it fulfills two properties, they are cohesion and coherence. According to them, cohesion is an internal property, while coherence is a contextual property. Cohesion is important to help a writer create a comprehending text, and is also important for the readers to construct a meaning.In addition to that, coherence is based more on the logic of the ideas and how a writer presents them. It is not how the language use to express these ideas. For a writing to be successful, it needs both cohesion and coherence. The statement is supported by O'Malley and Pierce in Novitasari (2018) who say that writing is not only about how to initiate the ideas, but also how to develop these ideas into unified thought. Hence, cohesion and coherece are required in writing a good composition.

In line with the previous definitions, Eggins (as cited in Ningsih, 2014, p. 10) defines the term "cohesion" to how parts of a discourse are related together. Cohesion denotes certain features of a text like the semantic tie in a text, the consistency of participant, and the connection in terms of lexical selections. Halliday and Hasan (in Ningsih, 2014, p. 11).) classify cohesion in English into two broad categories: grammatical cohesion and lexical cohesion. In grammatical cohesion, the relationship between and within a text is signed by means of grammatical elements. Meanwhile, lexical cohesion refers to how a writer uses lexical items such as nouns, verbs, adjectives, and adverbs to relate to the text consistently to its area of focus

The researcher conducted a preliminary study related to cohesion and coherence used by the sixth-semester students of English Education Program at the State Islamic University of Sultan Thaha Saifuddin Jambi. It was found out that most of the students have good writing skills that are proven by their publications in some academic journals. Besides, thesemost of these students always got an A in their writing classes. Having known this fact, the researchers wanted to find out how the students used cohesion and 
coherence that played part in the success of their writing.

\section{METHOD}

This study used a qualitative approach as an effort to provide answers to problems that have been laid out.. Qualitative method is ideal for a research which embeds a cultural aspect such as power distance, since it allows the researcher to investigate the small data in detailed and in depth manner (Creswell, 2007, p.16). Data collection techniques in this study were carried out by using a test and documentation. In this test, the researchers wanted the students to write descriptive text with the topic "tourism object that students have ever visited." The documentation was used to get the information such as the research place, organization structure, students' activities, students' worksheets, and documents. The participants in this research were twenty sixth-semester students of English Education Program at The State Islamic University of Sultan Thaha Jambi. The researchers chose these students because they finished Writing II and Writing III courses.

\section{FINDINGS AND DISCUSSION}

\section{Findings}

The types of cohesion used were reiteration and collocation. The finding showed that nine students used fifteen items of reiteration and one student used collocation. Related to the use of coherence, all students used repeated key nouns in their writing text with total 131 items. In addition to that, fifteen students used sixteen items of consistent pronouns. The finding can be seen in Table 1 . 
Table 1. The Result of research descriptive texts written by the sixth-semester students of English Education Program at The State Islamic University of Sultan Thaha.

\begin{tabular}{|c|c|c|c|c|c|}
\hline \multirow[t]{2}{*}{ No } & \multirow[t]{2}{*}{ Participants } & \multicolumn{2}{|c|}{$\begin{array}{l}\text { Lexical } \\
\text { Cohesion }\end{array}$} & \multicolumn{2}{|c|}{ Coherence } \\
\hline & & $\mathrm{Rt}$ & $\mathrm{Cc}$ & Rkn & Ucp \\
\hline 1 & Participant 1 & 1 & - & 8 & - \\
\hline 2 & Participant 2 & - & - & 8 & - \\
\hline 3 & Participant 3 & 1 & - & 6 & 1 \\
\hline 4 & Participant 4 & 1 & - & 2 & 1 \\
\hline 5 & Participant 5 & 1 & - & 11 & 1 \\
\hline 6 & Participant 6 & - & - & 4 & 1 \\
\hline 7 & Participant 7 & 3 & - & 7 & 1 \\
\hline 8 & Participant 8 & - & - & 2 & 1 \\
\hline 9 & Participant 9 & 1 & - & 8 & - \\
\hline 10 & Participant 10 & - & - & 3 & 1 \\
\hline 11 & Participant 11 & 3 & 1 & 7 & 2 \\
\hline 12 & Participant 12 & 3 & - & 4 & - \\
\hline 13 & Participant 13 & - & - & 1 & - \\
\hline 14 & Participant 14 & - & - & 2 & 1 \\
\hline 15 & Participant 15 & - & - & 6 & 1 \\
\hline 16 & Participant 16 & - & - & 5 & 1 \\
\hline 17 & Participant 17 & - & - & 9 & 1 \\
\hline 18 & Participant 18 & - & - & 8 & 1 \\
\hline 19 & Participant 19 & - & - & 6 & 1 \\
\hline 20 & Participant 20 & 1 & - & 8 & - \\
\hline 21 & Participant 21 & - & - & 9 & 1 \\
\hline 22 & Participant 22 & - & - & 7 & - \\
\hline Total & & 15 & 1 & 131 & 16 \\
\hline
\end{tabular}

Rt : Reiteration

Cc : Collocation

Rkn : Repeat Key Nouns

Ucp : Use Consistent Pronouns 
After conducting the research, the researchers found out that the students used some kinds of cohesion and coherence. The researchers analyzed the students' writing about tourism in the form of descriptive text. Then, the researchers found that the students used cohesion and coherence. In this case, the researchers only focused on some kinds of cohesion and coherence mostly used by the students. The followings are the detailed information about the types of cohesion and coherence used.

\section{Cohesion Use}

\section{Lexical Cohesion}

Lexical cohesion is important in a discourse. Jan Renkema (as cited in Efendi, 2011, p. 17) explains that "Lexical cohesion does not deal with grammatical and semantic connection but with connections based on the words used. There are two types of lexical cohesion: reiteration and collocation.

\section{a. Reiteration}

In general, reiteration is divided into some types. They are conference, synonymy, hyponymy, metonymy, and antonym. Based on the result, the students only used some kinds of reiteration, they are: hyponymy, synonymy, and antonym.

\section{i) Hyponymy}

Student A used the hyponym of monkey. She wrote "For those who love to see great apes including orang utans, chimpanzees, and gorillas." In another source, Student B used the hyponym of family member, as written in "Four years ago, I went to Jakarta. I visited my oldest brother. I went to Jakarta with my mother and my niece". Another result showed Student Cused the hyponym of Indonesia's kingdom as mentioned in text "In Muaro Jambi Temple there are some relief that come from Sriwijaya and Melayu Kingdom". The function of the hyponym in a text is to specify the meaning of a certain word(Efendi, 2011, p. 19). When a writer wants to explain a particular term in details, he or she can use a hyponym to elaborate the term. 


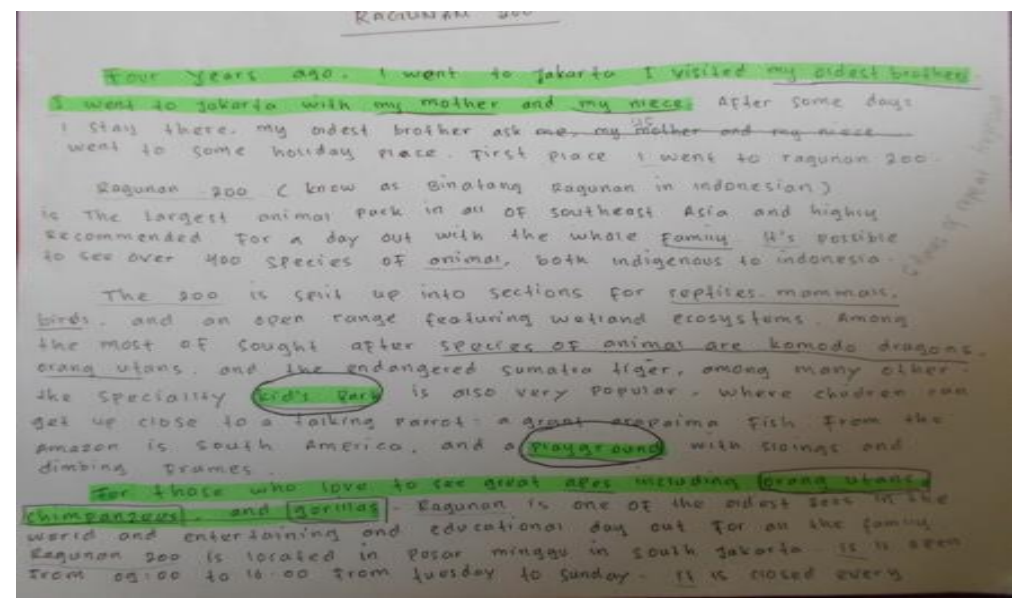

Figure 1. An example of hyponymy used in student's writing

ii) Synonymy

The researcher found some synonyms in students' writing. The use of much and many that were found in "Most of people always visit this tourism place because there are many flowers and also the park is very clear. Ancol Sarolangun is a place when the teenager can spend much time." Other than that, the researchers also found the synonym of near and close from the text," I stay at a hotel near Jam gadang. It is so close to Pasar atas. By using a word synonym in a text, we can avoid repeating the same words in the same text.

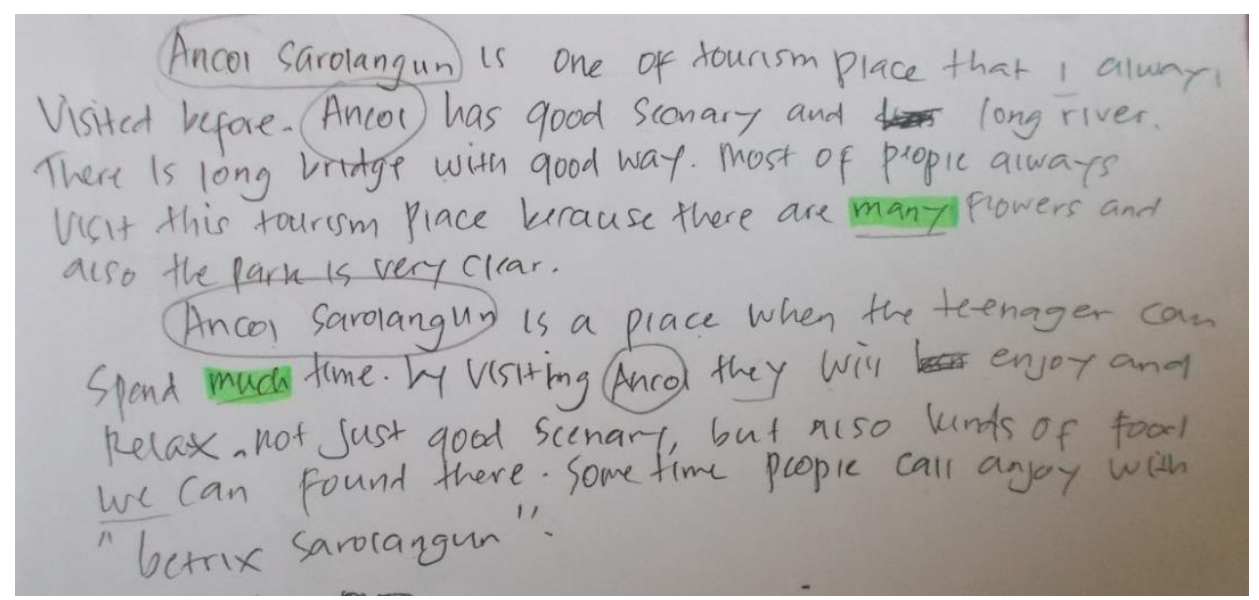

Figure 2. An example of synonymy used in student's writing

iii) Antonym

The researchers also found some use of antonyms in students' writing; The first antonym, far and near were found in sentence; "This place is located in Muaro Jambi and so far from Jambi City. This place is located in Jambi City market near 
to the Ramayana Dept. Store building" From another text, inside and outside were used by the student: "A lot of tourist from inside and outside the city who visit this island to enjoy the beauty of this place, people around this island is also friendly to people who visit". Young and old were found in sentence "Sarolangun ancol is the place where the young and old people can spend much time."Ina text, antonym is used to show the opposite relations between a word (Murphy, 2003).

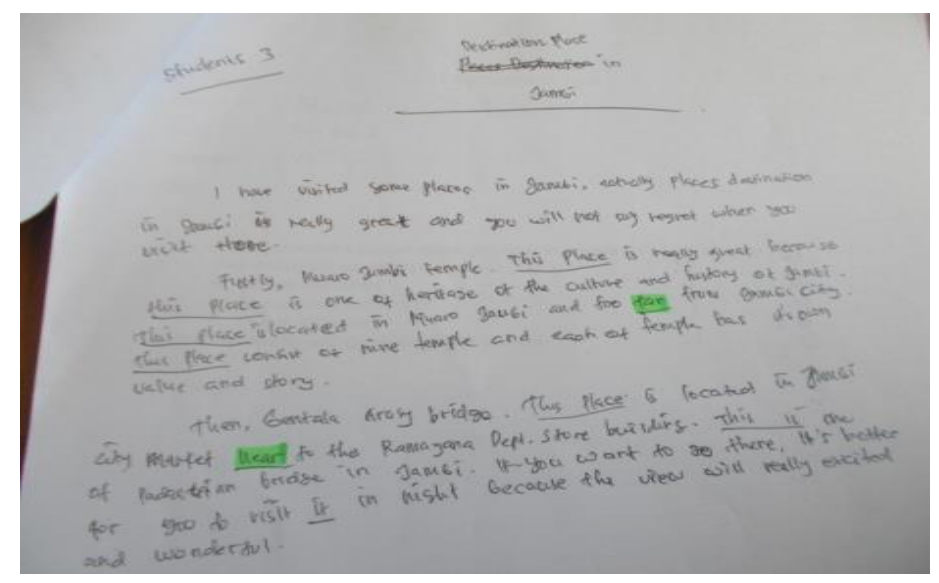

Figure 3. An Example of Antonym in Student's writing

\section{b. Collocation}

The researcher found only one student used a collocation. The collocation that was used by the student was kid's park and playground. "The speciality kid's park is also very popular, where children can get up close to a talking parrot : a grant arapaima fish from the amazon is south America, and a playground with sloings and dimbing frames". The use of collocation in writing is to create the natural situation, and it will be easier to understand.

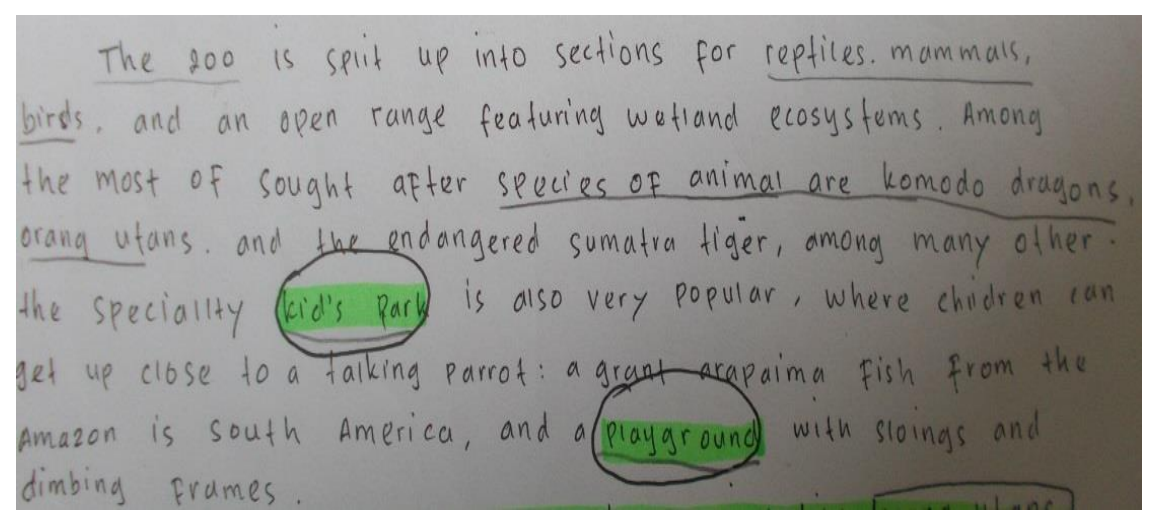

Figure 4. An Example of Collocation Used in Student's Writing 


\section{Coherence Use}

According to Oshima and Hogue (2006, p. 22), there are four ways to achieve coherence. There are repeating key nouns, using consistent pronouns, using transition signals to link ideas, and arrangingideas in a logical order. However, in this research, the researchers only focused on the repeated key nouns and the use of consistent pronouns.

\section{a. Repeated Key Nouns}

The main thing that is done to establish cohesion in a part of the text is to duplicate the key nouns. However, a writer can also duplicate other classes of words, whenever they are important in a text, and there is no certain rule how many nouns that can be duplicated or used sparingly in a text. However, there is another alternative, namely using the same word meaning.

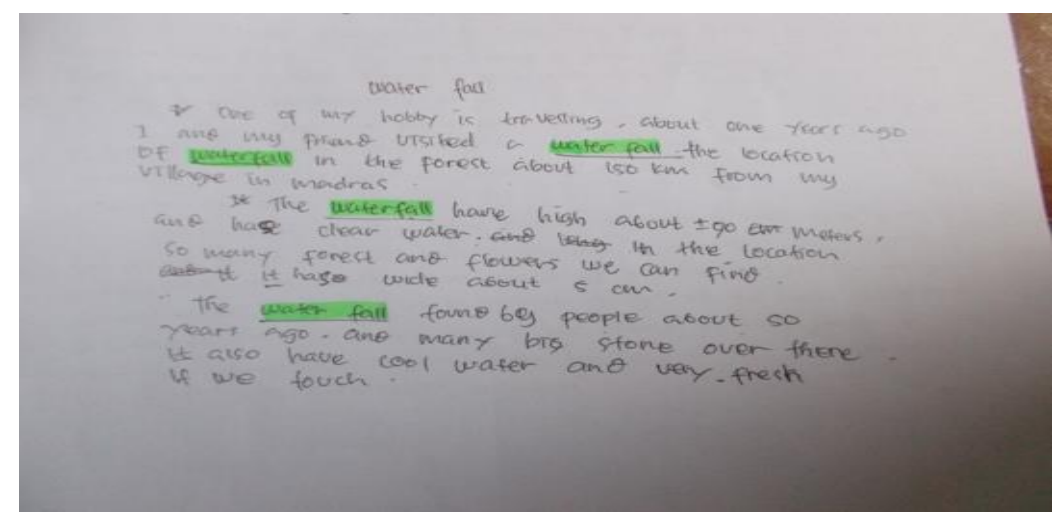

Figure 5. An Example of Repeated Key Nouns in Student's Writing

From text, we can see the use of repeated key noun. The text above is about waterfall in the writer's village, and the repeated key noun appeared four times. repeated key noun appeared twice the first paragraph, one time in the second paragraph, and one time in the third paragraph. All students in this class used repeated key noun that means that they have a good writing.

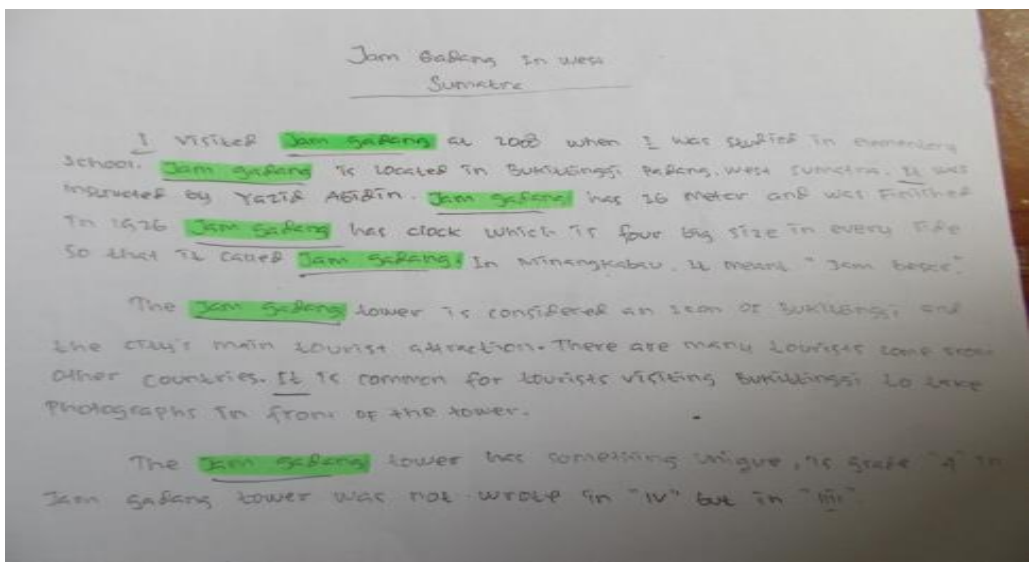

Figure 6. An example of repeated key noun in student's writing 
From the text, we can find some repeated key noun. The text above is about Jam gadang in West Sumatera. ased on the text, the writer told that she visited the site when she was a child. The repeated key noun appeared seven times. Every paragraph has a repeated key noun, and some of them can be found in the first paragraph.

\section{b. Use of Consistent Pronouns}

The consistent use of pronouns is to change the noun with a more effective pronoun. A text will look more beautiful with pronouns. The most important thing in changing a noun into a pronoun is when the writer is consistent in using the same pronoun in a paragraph. In most of their writing, the students used consistent pronouns.

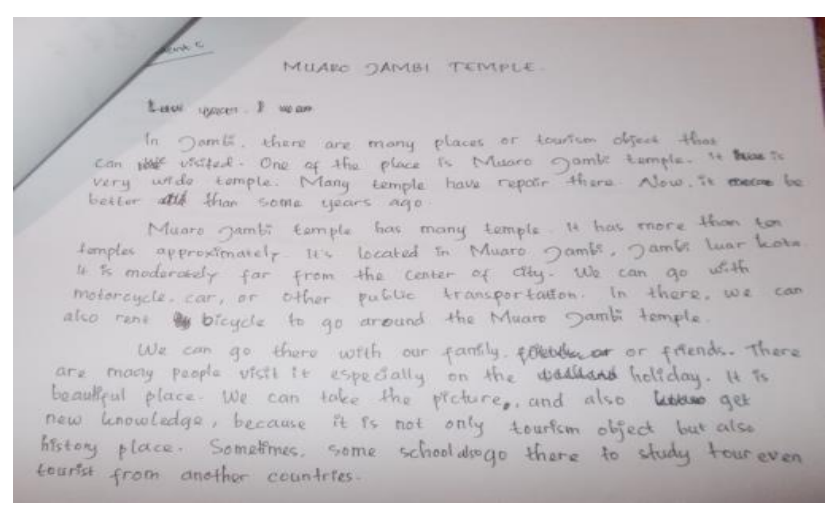

Figure 7. An Example of Consistent Pronouns in Student's Writing

From the text, we can see the use of consistent pronouns "we". The text above is about Muaro Jambi Temple. The writer consistently used pronouns from the first paragraph until the last paragraph. By using the same pronoun several times, the writer was sure about the point of view of as a writer.

\section{CONCLUSIONS AND SUGGESTIONS}

\section{Conclusions}

The sixth-semester students have used cohesion and coherence well in their writing. It can be seen from the types of cohesion and coherece use in their writing that is quite varied. The use of cohesion and coherence in their writing shows that the students are able to create a good, interesting, and meaningful text. This also helps the readers understand the content easier. Thus, the researchers can conclude that students' good writing has already involved the use of cohesion and coherence in their writing. 


\section{Suggestions}

After conducting the research, the researcher found that the students had some difficulties in using collocation and consistent pronoun. Hence, for the next research, it would be good to give more attention to students' understanding on collocation and consistent pronoun.

\section{REFERENCES}

Alice Oshima and Ann Hogue, (2007). Introduction to Academic Writing. New York Pearson Education. Inc.

Creswell, J. W. (2007). Educational research: planning,conducting and evaluating quantitative and qualitative research. $\left(4^{\text {th }}\right.$ ed).US: Pearson Education.

Efendi. (2011). Cohesion and Coherence In Conversations Between Students Of Language And English Literature Department Of Adab Faculty And Foreigners. Jambi Thesis Unpublished.

Harmer, Jeremy. (2001). How to Teach Writing. Harlow: Pearson Education Ltd

Kurniasih, Y. (2015). Students' Coherence In Writing Descriptive Text At Fifth Semester Of English Education Program The State Institute For Islamic Studies Sulthan Thaha Saifuddin Jambi. Jambi Thesis Unpublished.

Murphy, M. Lynne. (2003). Semantic relations and the lexicon: Antonymy, synonymy, and other paradigms. Cambridge: Cambridge University Press.

Ningsih A. (2014). An Analysis of Descriptive text Written By Eight Grade Students at Islamic Junior High School Asas Islamiyah Jambi. Jambi Thesis Unpublished.

Novitasari, N. F. (2018). Experiential learning: A means to rocket students' low motivation and writing skills. In International English Languages Teachers and Lecturers Conference. Malang, Indonesia.

Witte, S., and Faigley, L. (1981). Coherence, cohesion, and writing quality. College Composition and Communication, 37 (1), 22-29.

Zemach, D.E,\& Rumizek, A.L (2005). Academic Wriiting from Paragraph to Essay. Macmillan Publishers. 